Original Article

\title{
Occupational participation, stress, anxiety and depression in workers and students from Brazilian universities during the COVID-19 pandemic
}

\author{
Participação ocupacional, estresse, ansiedade e depressão em \\ trabalhadores e estudantes de universidades brasileiras durante a \\ pandemia de COVID-19
}

Glenda Miranda da Paixão ${ }^{a}$ (D), Adriene Damasceno Seabra ${ }^{a}$ (D), Adrine Carvalho dos Santos Vieira ${ }^{a}$ (D), Julia Andreza Gorlab (D), Daniel Cezar da Cruz ${ }^{\mathrm{c}}$ (D)

${ }^{a}$ Universidade Federal do Pará - UFPA, Belém,PA, Brasil.

${ }^{b}$ Universidade Federal de São Carlos - UFSCar, São Carlos, SP, Brasil.

'Leeds Beckett University - LBU, Leeds, United Kingdom.

How to cite: Paixão, G. M., Seabra, A. D., Vieira, A. C. S., Gorla, J. A., \& Cruz, D. C. (2022). Occupational participation, stress, anxiety and depression in workers and students from Brazilian universities during the COVID-19 pandemic. Cadernos Brasileiros de Terapia Ocupacional, 30, e2952. https://doi.org/10.1590/2526-8910

\begin{abstract}
$\underline{\text { Abstract }}$
Introduction: The physical, social and occupational restrictions imposed by the COVID-19 pandemic have affected the health and well-being of the world population. Objective: To identify the repercussions of the pandemic on the occupational participation of students, lecturers and technicians from three public universities in Northern Brazil, to compare the changes reported by participants in occupational participation before and during the pandemic, and to identify symptoms of depression, anxiety and stress self-reported. Method: This is a Crosssectional, descriptive and comparative study with a quantitative approach. One hundred and ninety-nine $(\mathrm{n}=199)$ participants (students, lecturers and technicians) responded to an online questionnaire, the "Occupational Participation Checklist" and the Anxiety, Stress and Depression Scale (DASS-21). Data analysis were descriptive and also performed by applying the Wilcoxon and Mann-Whitney tests. Results: During the pandemic, an increase in occupational participation was identified for all participants in domestic activities $(p<0.001)$ and a decrease in work and study face to face $(\mathrm{p}<0.001)$. Students reported more symptoms of depression, anxiety and stress when compared to lecturers $(\mathrm{p}<0.001)$. Most students did not organise their time to fulfil their occupations with satisfaction. Such difficulties were associated with symptoms of depression, anxiety and stress,
\end{abstract}


especially among the student's group $(\mathrm{p}<0.001)$. Conclusion: This study provided preliminary evidence about differences in occupational participation before and during the Covid-19 pandemic. The organization of time and difficulties in occupational participation were associated to levels of anxiety, depression and stress, especially in the sample of students.

Keywords: Activities of Daily Living, COVID-19, Universities, Work, Anxiety, Occupational Therapy.

\section{$\underline{\text { Resumo }}$}

Introduçáo: As restriçóes físicas, sociais e ocupacionais impostas pela pandemia de COVID-19 têm afetado a saúde, o bem-estar e a qualidade de vida da população mundial. Objetivo: Identificar as repercussóes da pandemia na participação ocupacional de estudantes, docentes e técnicos de três universidades públicas do Norte do Brasil, comparar as mudanças relatadas pelos participantes na participaçáo ocupacional antes e durante a pandemia, e identificar sintomas de depressão, ansiedade e estresse. Método: Estudo transversal, descritivo e comparativo com abordagem quantitativa. Cento e noventa e nove $(n=199)$ participantes (alunos, professores e técnicos), responderam (on-line) à "Lista de Verificação da Participação Ocupacional" e à Escala de Ansiedade, Estresse e Depressão (DASS-21). Realizou-se análise descritiva dos dados e aplicaçáo dos testes de Wilcoxon e Mann-Whitney. Resultados: Durante a pandemia, identificou-se aumento na participação ocupacional para todos os participantes nas atividades domésticas $(\mathrm{p}<0,001)$ e diminuição no trabalho ou estudos presenciais ( $\mathrm{p}<0,001)$. Os alunos relataram mais sintomas de depressão, ansiedade e estresse em comparação com os professores $(\mathrm{p}<0,001)$. A maioria dos estudantes não organizou seu tempo para desempenhar, com satisfação, suas ocupaçóes. Tais dificuldades foram associadas com sintomas de depressão, ansiedade e estresse, principalmente entre os estudantes $(p<0,001)$. Conclusão: Este estudo forneceu conclusóes preliminares sobre as diferenças na participação ocupacional antes e durante a pandemia. A organização do tempo e as dificuldades no desempenho das ocupaçóes foram relacionadas aos níveis de ansiedade, depressão e estresse, principalmente na amostra de estudantes.

Palavras-chave: Atividades Diárias, COVID-19, Universidades, Trabalho, Ansiedade, Terapia Ocupacional.

\section{Introduction}

In December 2019, many local health facilities in Wuhan, China, reported a group of patients with pneumonia from an unknown cause. The virus rapidly spread across countries. The World Health Organization (WHO) declared, on 30th January 2020, that COVID-19 was a Public Health emergency of international importance - the highest level of alert of WHO (World Health Organization, 2020). Public health measures were adopted by several countries to decrease the number of transmissions and infections. Among those measures, social distancing and social isolation were the main strategies to avoid the spread of the COVID-19 (Centers for Disease Control and 
Prevention, 2020; Ledford et al., 2020; Organização Pan-Americana da Saúde, 2020). In Brazil, despite the lack of action by the Brazilian Government the Ministry of Health (Brasil, 2020) has insisted on recommendations of hygiene, social isolation and social distancing measures. Although data on the results of social distancing in Brazil were not found (only data from some states), these measures have shown efficacy in reducing the epidemic curve, enabling time for crucial increases in the capacity of the health-care system, and to develop effective strategies for treatment and prevention (Matrajt \& Leung, 2020; Moraes, 2020). These measures required arrangements by the university staff for home office and online teaching since March 2020.

Although such measures are positive, on the other hand, they impact on people's occupational lives, families, communities and institutions, forcing changes in habits and occupational roles (i.e.: worker, student, hobbyist, family member and religious observance, among others), in the physical, social and occupational environment, and dynamically in people's motivation (Kielhofner, 2008; Lin \& Fisher, 2020; Pablo et al., 2017). As a result of this, problems in occupational adaptation ${ }^{1}$ emerge, since the identity, competency and environment impact on people's lives. An example of this hypothesis is seen in the communities within universities, where the absence of work in those places was suspended, "opening the doors to people's homes" in what is known as "home-office", including "virtual classrooms" thus, altering the immediate environment (Lin \& Fisher, 2020; Fisher et al., 2017), the relationships with social groups (Kielhofner, 2008; Lin \& Fisher, 2020), and, in other words, putting the work inside people's houses.

In the universities, the suspension of academic activities in the public spaces implied a rupture in temporality, social movement, spaces and social relationships related to those spaces. Such restrictions can be overwhelming and producing the feeling of un-productivity (Teixeira \& Dahl, 2020). In hypothesis, such examples show how occupational participation is affecting individuals' engagement, once their subjective experience produces negative thoughts and feelings influenced by the environmental restrictions caused by pandemics.

The World Federation of Occupational Therapists, in a public note, recognises that COVID-19 is impacting profoundly on the health and wellbeing of individuals, families and communities worldwide; mainly on the way people can access, and perform their occupations. This context includes modifications in the access of resources, daily activities, communication, mobility, social participation, mental health and wellbeing issues (World Federation of Occupational Therapy, 2020). Other implications include uncertainties about the future, alterations in self-efficacy, engagement in interests, daily routines, occupational roles and the environment of a person (Lin \& Fisher, 2020).

Despite recent initiatives to continue the remote work at the universities (Silva et al., 2020b; Teixeira \& Dahl, 2020), we did not find data related to the impact of these changes on occupational participation and routine of the communities in the university. Several studies from different countries report the negative effects of COVID-19 between university students; such anxiety, stress, depression, and patterns of sleep (Husky et al., 2020; Cao et al., 2020; Marelli et al., 2020; Islam et al., 2020; Liang et al., 2020; Ozamiz-Etxebarria et al., 2020).

\footnotetext{
${ }^{1}$ Occupational adaptation is a combination of identity (who you are and want to be, your occupational role, your sense of routine and effectiveness for doing things, and the interest and satisfaction to do them) and competency, (skills to put the identity in action, in order to sustain a pattern of occupational participation) considering the environment (Kielhofner, 2008).
} 
Nonetheless, the aim of this research is to identify the repercussions of the COVID19 pandemic on occupational participation of students, and the university staff (lecturers and technicians) in three public universities in the North of Brazil, and to compare changings in occupational participation both before and during the pandemics as reported by the participants, and to identify symptoms of depression, anxiety and stress.

\section{Methods}

This research is a cross-sectional, descriptive and comparative study with a quantitative approach. The research project was approved by the Institutional Review Board under number 32816020.5.0000.0018.

\section{Participants}

A convenience sample of three public universities (one State and two Federal) was recruited with the following criteria:

Inclusion criteria: 1) being a student, professor or technician (i.e. secretary, therapy assistant) of the university; 2) Not being at work or study from the university physical spaces due to the pandemic (carrying out their activities remotely online); 3) Students who started the undergraduate programme until 2020.

Exclusion criteria: 1) not being a student, professor or technician (i.e. secretary, therapy assistant) of the three universities cited; 2) currently working or studying at the university physical spaces (face to face).

One hundred ninety nine participants responded to the research: females: $75.7 \%$ $(\mathrm{n}=106)$ students, $76.2 \%(\mathrm{n}=32)$ lecturers and $88.2 \%(\mathrm{n}=15)$ technicians. Male: $24.3 \%$ $(\mathrm{n}=34)$ students, $23.8 \%(\mathrm{n}=10)$ lecturers and $11.8 \%(\mathrm{n}=02)$ technicians. The age average in the groups of students, lecturers and technicians was respectively, 23.2 (DP 5.2), 37.8 (DP 9.0) e 32.1 (DP 4.2) years old.

Instruments of data collection

1) Checklist of Occupational Participation before and during the pandemic

The authors created a form which could inform the study using a range of occupations, with the aim of identifying changes before and during the pandemic, related to activities engaging the community in the past (before the pandemic) or currently engaged in (during the pandemic). The authors discussed finding a systematic way to gather the data in a way which would allow comparison between the samples. An electronic form was created by the group of research bases, inspired by measures of interest and occupational participation (Kielhofner \& Neville, 1983; Oakley et al., 1986). Our form is presented in the Appendix 1 of this manuscript. The researchers discussed the concept of occupational participation in order to inform what people do or did; thus, the checklist should ask the participants not hypothetical questions like "if you" or "would you", but actually what they had performed or were still performing, in order to represent the concept of occupational participation in "doing things". Rather than only state the word "participate", we opted for "I participate" to affirm the commitment of the respondent in the occupational engagement when reporting the participation (Forsyth \& Kielhofner, 2008). It is important to highlight that this form 
was developed specifically for the research purpose and it is not an instrument translated and/or validated to Brazilian population.

The form comprised two sections: 1) Level of interest in occupations before and during the pandemic; 2) Checklist of occupations where the participants could rate their participation "before" and "after" the pandemic in a Likert scale of 4 points. They could mark only one option for before and during the pandemic: $0=$ "I do not participate", 1 = "I participate", 2= "I participate moderately" and 3= "I participate vigorously".

The last part of the form was descriptive and referred to routine questions where the respondent should mark: "Yes" or "No" about information they identify, relating to organizing their time, new habits made, and activities engaged in, and ability to sustain them, as important dimensions of occupational engagement (Forsyth \& Kielhofner, 2008).

2) Depression Anxiety Stress Scale-21

This is a "self-report" instrument, composed of three subscales with seven items each, in order to measure depression, anxiety and stress in the past week, adapted and validated for Brazil by Vignola \& Tucci (2014). Answers are provided in a Likert Scale, ranging from zero (totally disagree) to three (totally agree). Global scores are calculated for these three constructs by a total of the seven scores multiplied by two. Scores can correspond to levels of symptoms from "normal” to "very severe" (Silva et al., 2020a).

\section{Data collection procedure}

To gather the data safely in the face of the pandemic and its social isolation, the authors conducted the research using online forms which were sent to the students, lecturers and technicians of the three universities; by email and social media. We also utilised the snow ball technique, where participants indicated other potential participants to join the research. The participants received the following information: research aim, methodological procedures and a Free Consent Inform Term. After reading all instructions, the participants signed electronically to authorize their participation in the research. After this, they could access the link to respond to the research which was available during thirty days between the months June and July of 2020. In total, 289 participants responded the questionnaire, however 90 were excluded because they were not students, lecturers or technicians in one of the three universities considered for this research. There were no forms with blank answers.

\section{Data analysis}

All data was organised in tables using the Microsoft Excel $^{\varpi}$ software, and statistical analysis was performed by the Software Bioestat 5.0. Initially, we carry out a descriptive analysis to carachterise the sample using demographics and daily routine data. To verify differences on the level of participation before and during the pandemic, the Wilcoxon Test was applied. For the Depression Anxiety Stress Scale-21, we utilised mean scores of each subscale for each group of participants and the normality test Shapiro-Wilk, followed by the Mann-Whitney in order to identify differences between students, lecturers and technicians. The level of significance considered was $\mathrm{p}<0.05$. 


\section{Results}

Our findings show that more than a half of students did not manage to organise their time performing, with satisfaction, the work they need to do during the pandemics, while $52.4 \%$ of the lecturers and $58.8 \%$ of technician informed that they managed to complete their activities during the same period. Most of the students $(89.3 \%)$, lecturers $(78.6 \%)$ and technicians $(76.5 \%)$ reported difficulties in participation of all occupations they wanted or were expected to do. Among students, $78.6 \%$ started new habits/activities and $55.7 \%$ sustained the participation, while $92.9 \%$ lecturers and $82.4 \%$ of technicians also began new habits and activities and sustained them, respectively, $76.2 \%$ and $70.6 \%$, as presented in Table 1.

Table 1. Routine of the participants during the pandemic ( $\mathrm{n}=199)$.

\begin{tabular}{lcccccccc}
\hline Participants & $\begin{array}{c}\text { Difficulties on } \\
\text { occupational } \\
\text { participation }\end{array}$ & $\begin{array}{c}\text { Started new } \\
\text { habits and } \\
\text { activities }\end{array}$ & $\begin{array}{c}\text { Sustained the } \\
\text { new habits and } \\
\text { activities }\end{array}$ & $\begin{array}{c}\text { Time } \\
\text { organisation to } \\
\text { perform } \\
\text { occupations }\end{array}$ \\
\hline Students & $\mathbf{n}$ & $\mathbf{\%}$ & $\mathbf{n}$ & $\mathbf{\%}$ & $\mathbf{n}$ & $\mathbf{\%}$ & $\mathbf{n}$ & $\mathbf{\%}$ \\
\hline Yes & 125 & 89.3 & 110 & 78.6 & 78 & 55.7 & 38 & 27.1 \\
\hline No & 15 & 10.7 & 30 & 21.4 & 62 & 44.3 & 102 & 72.9 \\
\hline Lecturers & $\mathbf{n}$ & $\mathbf{\%}$ & $\mathbf{n}$ & $\mathbf{\%}$ & $\mathbf{n}$ & $\mathbf{\%}$ & $\mathbf{n}$ & $\mathbf{\%}$ \\
\hline Yes & 33 & 78.6 & 39 & 92.9 & 32 & 76.2 & 22 & 52.4 \\
\hline No & 9 & 21.4 & 3 & 7.1 & 10 & 23.8 & 20 & 47.6 \\
\hline Technicians & $\mathbf{n}$ & $\mathbf{\%}$ & $\mathbf{n}$ & $\mathbf{\%}$ & $\mathbf{n}$ & $\mathbf{\%}$ & $\mathbf{n}$ & $\mathbf{\%}$ \\
\hline Yes & 13 & 76.5 & 14 & 82.4 & 12 & 70.6 & 10 & 58.8 \\
\hline No & 4 & 23.5 & 3 & 17.6 & 5 & 29.4 & 7 & 41.2 \\
\hline
\end{tabular}

$\mathrm{n}=$ number of participants.

Additionally, Table 2 depicts a comparison of occupational participation of the sample before and during the COVID-19 pandemic, showing what had changed significantly. The students were the group with major statistical differences in occupational participation before and during the current pandemic. The differences refer to an increase of occupational participation in watching TV $(\mathrm{p}<0.001)$, housekeeping $(\mathrm{p}<0.001)$, and other occupations. However, a decrease in occupational participation in studying $(\mathrm{p}<0.001)$, exercising $(\mathrm{p}<0.001)$ and being a volunteer $(\mathrm{p}<0.001)$, can be identified among students.

Table 3 presents comparisons between groups for the variables of depression, anxiety and stress. The students had significantly more depression ( $\mathrm{p}<0.001)$, anxiety $(\mathrm{p}<0.001)$ and stress $(\mathrm{p}<0.001)$ when compared to lecturers. The group of students had more depressive symptoms $(p=0.002)$ and anxiety $(p=0.016)$ than the technicians. By comparing the groups, it can be seen that students had significant differences related to those symptoms. However, no statistical differences were observed between lecturers and technicians in all scales. 
Table 2. Comparison of occupational participation before and during COVID-19 pandemic using the Wilcoxon Test $(\mathrm{n}=199)$.

\begin{tabular}{|c|c|c|c|c|c|c|}
\hline \multirow{2}{*}{ Occupation } & \multicolumn{2}{|c|}{ Students } & \multicolumn{2}{|c|}{ Lecturers } & \multicolumn{2}{|c|}{ Technicians } \\
\hline & $\mathbf{Z}^{2}$ & p value & $\mathrm{Z}$ & p value & $\mathbf{Z}$ & p value \\
\hline Hand crafts & 1.667 & 0.096 & 1.245 & 0.213 & 1.826 & 0.068 \\
\hline Watch TV & 6.874 & $<0.001^{* *}$ & 3.403 & $<0.001^{* *}$ & 2.170 & $0.030^{*}$ \\
\hline Take care of children & 2.666 & $0.008^{*}$ & 3.059 & $0.002^{*}$ & 2.201 & $0.028^{*}$ \\
\hline Self Care & 3.227 & $<0.001^{* *}$ & -1.275 & 0.202 & 0.235 & 0.814 \\
\hline Gardening & 4.241 & $<0.001^{* *}$ & 1.782 & 0.075 & 2.578 & $0.010^{*}$ \\
\hline Domestic activities & 8.329 & $<0.001^{* *}$ & 4.967 & $<0.001^{* *}$ & 3.408 & $<0.001^{* *}$ \\
\hline Take care of pets & 5.233 & $<0.001^{* *}$ & 2.803 & $0.005^{*}$ & 2.201 & $0.028^{*}$ \\
\hline Cooking & 7.705 & $<0.001^{* *}$ & 4.475 & $<0.001^{* *}$ & 2.870 & $0.004^{*}$ \\
\hline Studying & -8.066 & $<0.001^{* *}$ & -0.829 & 0.407 & -1.022 & 0.307 \\
\hline Writing & -4.351 & $<0.001^{* *}$ & 1.189 & -0.234 & -1.067 & 0.286 \\
\hline Physical activity & -3.240 & $<0.001^{* *}$ & 0.062 & -0.951 & -1.294 & 0.196 \\
\hline Play & 7.290 & $<0.001^{* *}$ & 1.886 & 0.059 & 1.859 & 0.063 \\
\hline Reading & 0.853 & 0.394 & 0.067 & 0.946 & -0.445 & 0.657 \\
\hline Meditation & 2.952 & $0.003^{*}$ & 3.039 & $0.002^{*}$ & 1.095 & 0.273 \\
\hline Listening music & 3.711 & $<0.001^{* *}$ & 1.633 & 0.102 & 0.652 & 0.515 \\
\hline Using social media & 6.353 & $<0.001^{* *}$ & 3.719 & $<0.001^{* *}$ & 2.666 & $0.008^{*}$ \\
\hline $\begin{array}{l}\text { Work from the university } \\
\text { office }\end{array}$ & -7.676 & $<0.001^{* *}$ & -5.162 & $<0.001^{* *}$ & -3.516 & $<0.001^{* *}$ \\
\hline Work remotely & 2.816 & $0.005^{*}$ & 5.373 & $<0.001^{* *}$ & 3.296 & $<0.001^{* *}$ \\
\hline Volunteering & -6.232 & $<0.001^{* *}$ & -1.138 & 0.255 & -0.802 & 0.423 \\
\hline Learn new skills & 1.068 & 0.285 & 0.628 & 0.530 & 0.944 & 0.345 \\
\hline Caregiving & 4.859 & $<0.001^{* *}$ & 3.180 & $0.002^{*}$ & 1.826 & 0.068 \\
\hline
\end{tabular}

${ }^{2} \mathrm{~A}$ positive $\mathrm{Z}$ score indicates that the value is above average and a negative $\mathrm{Z}$ score means that the value is below average. ${ }^{*} \mathrm{p}<0.05 ;{ }^{* *} \mathrm{p}<0.001$.

Table 3: Median and $p$-values by comparing groups using the Mann-Whitney test ( $n=199)$.

\begin{tabular}{|c|c|c|c|c|c|c|c|c|c|}
\hline \multirow{2}{*}{ Scale } & \multicolumn{3}{|c|}{ Students $\mathrm{x}$ Lecturers } & \multicolumn{3}{|c|}{ Students $\mathbf{x}$ Technicians } & \multicolumn{3}{|c|}{ Lecturers $x$ Technicians } \\
\hline & $S$ & $\mathbf{P}$ & p-value & $S$ & $\mathbf{T}$ & p-value & $\mathbf{P}$ & $\mathbf{T}$ & p-value \\
\hline Depression & 22 & 10 & $<0.001^{* *}$ & 22 & 10 & $0.002^{*}$ & 10 & 10 & 0.788 \\
\hline Anxiety & 19 & 8 & $<0.001^{* *}$ & 19 & 6 & $0.016^{*}$ & 8 & 6 & 0.853 \\
\hline Stress & 26 & 20 & $0.001^{*}$ & 26 & 20 & 0.167 & 20 & 20 & 0.37 \\
\hline
\end{tabular}

Subtitles: ${ }^{*} \mathrm{p}<0.05 ;{ }^{* *} \mathrm{p}<0.001 ; \mathrm{S}=$ Student; $\mathrm{P}=$ Lecturers; $\mathrm{T}=$ Technicians.

Finally, Table 4 presents the comparisons of time organisation and difficulties in performing occupations with symptoms of anxiety, depression and stress among the three groups of participants. We observed that among the students group, there was a significant difference in the levels of depression $(\mathrm{p}<0.001)$, anxiety $(\mathrm{p}=0.006)$ and stress $(\mathrm{p}=0.002)$, between the participants who had difficulty with time organisation and those 
who did not. Moreover, a significant difference was also found between participants who had difficulties on occupational participation they wanted, or expected to do, and those who did not experience difficulty, in the symptoms of depression $(\mathrm{p}<0.001)$, anxiety $(\mathrm{p}=0.001)$ and stress $(\mathrm{p}=0.007)$ among students, and in the symptoms of depression $(\mathrm{p}=0.018)$ and stress $(\mathrm{p}=0.015)$ for lecturers.

Table 4. Comparison between time organisation and difficulties in occupational participation with symptoms of anxiety, depression, and stress in the sample using the Mann-Whitney test $(n=199)$.

\begin{tabular}{|c|c|c|c|c|c|c|c|c|c|}
\hline \multirow{2}{*}{$\begin{array}{c}\text { Time } \\
\text { organisation }\end{array}$} & \multicolumn{3}{|c|}{ Students } & \multicolumn{3}{|c|}{ Lecturers } & \multicolumn{3}{|c|}{ Technicians } \\
\hline & $\begin{array}{c}\text { Median } \\
\text { Yes }\end{array}$ & $\begin{array}{c}\text { Median } \\
\text { No }\end{array}$ & p-value & $\begin{array}{c}\text { Median } \\
\text { Yes }\end{array}$ & $\begin{array}{c}\text { Median } \\
\text { No }\end{array}$ & p-value & $\begin{array}{c}\text { Median } \\
\text { Yes }\end{array}$ & $\begin{array}{c}\text { Median } \\
\text { No }\end{array}$ & p-value \\
\hline Depression & 13 & 24 & $<0.001^{* *}$ & 08 & 12 & 0.099 & 11 & 10 & 0.305 \\
\hline Anxiety & 10 & 20 & $0.006^{*}$ & 05 & 09 & 0.162 & 04 & 12 & 0.057 \\
\hline Stress & 20 & 29 & $0.002^{*}$ & 13 & 24 & 0.096 & 10 & 32 & 0.079 \\
\hline \multirow[b]{2}{*}{$\begin{array}{l}\text { Occupational } \\
\text { participation }\end{array}$} & \multicolumn{3}{|c|}{ Students } & \multicolumn{3}{|c|}{ Lecturers } & \multicolumn{3}{|c|}{ Technicians } \\
\hline & $\begin{array}{c}\text { Median } \\
\text { Yes }\end{array}$ & $\begin{array}{c}\text { Median } \\
\text { No }\end{array}$ & p-value & $\begin{array}{c}\text { Median } \\
\text { Yes }\end{array}$ & $\begin{array}{c}\text { Median } \\
\text { No }\end{array}$ & p-value & $\begin{array}{c}\text { Median } \\
\text { Yes }\end{array}$ & $\begin{array}{c}\text { Median } \\
\text { No }\end{array}$ & p-value \\
\hline Depression & 22 & 12 & $<0.001^{* *}$ & 12 & 02 & $0.018^{*}$ & 10 & 12 & 0.610 \\
\hline Anxiety & 20 & 08 & $0.001^{*}$ & 08 & 02 & 0.269 & 06 & 13 & 0.954 \\
\hline Stress & 28 & 18 & $0.007^{*}$ & 24 & 10 & $0.015^{*}$ & 20 & 20 & 0.650 \\
\hline
\end{tabular}

${ }^{*} \mathrm{p}<0.05 ;{ }^{* *} \mathrm{p}<0.001$.

\section{Discussion}

As we expected, all groups had significant differences on occupational participation before and during the pandemic, since significant changes were identified, mainly related to social distancing measures (Lin \& Fisher, 2020). It can be discussed that occupational participation increased with the social isolation measures. This fact can be explained due to the amount of tasks and overlap of roles during this period that does not mean an increasing of the quality on occupational participation. Moreover, difficulties in occupational participation found mainly in the group of students where the level of depression, anxiety and stress were higher can mirror the difficulties with time use to satisfactory accomplish planned taks, to sustain new habits and activities, since new tasks were initiated however did not have continuity.

We only found significant decrease in occupational participation in work from the university office (face to face) for the group of workers (lecturers and technicians); however, this result was expected due to the social distancing and social isolation measures imposed by public health and universities local public polices. These health public measures required workers to transfer their occupational environment of work into their houses, increasing the home office (Lin \& Fisher, 2020).

This result was different for the student group, where we found a decrease of activities possibly related to responsibilities or external sense of obligation (study) followed by an increase of leisure or hobby activities. On the other hand, for workers, we found, as expected, that occupational participation in work was continuous, but substituted by "home office"; not only because it is an internal role, but because policy at the universities imposed this condition on them, without any additional social support to implement the work at home. As a consequence of this, we cannot identify 
any increase in occupational participation in free time activities like leisure, self-care, listening to music as we were able to identify with the student group.

The lack of free time for the "worker groups" indicates an overwhelming amount of activities commensurate with responsibilities in occupational roles; such as taking care of children and pets, domestic activities, cooking and often being carer of someone who is ill. It is important to discuss that changing the home environment to a "home office" and sustaining this for several months full-time work, with limits which are unfamiliar, between the established borders of work commitments and domestic activities and family occupational roles which potentially presents negative consequences (not much explored, yet) for health care and education workers (Souza et al., 2021).

In addition, to performing the activities of a "home-office", the workers had often to abruptly adapt their technological tools, learning how to work in the "virtual environment", as we mentioned before, without any extra financial or social support for it. On this point, Rafael et al. (2020) emphasizes that public social policies might have to rethink things, in order to better protect workers, by investing in health care and social protection in Brazil.

Our findings about occupational participation of the respondents can be supported by a recent study conducted by Brooks et al. (2018), where they state that it is this occupational imbalance, followed by a sudden routine change during the COVID-19 pandemic, which can lead to consequences in health conditions, by diminishing quality and quantity of sleep, and increasing stress and feelings of frustration. Health problems associated with the routine change are also reported for health care workers, where symptoms of stress, fatigue were seen and "Burnout Syndrome" (Mheidly et al., 2020; Vindegaard \& Benros, 2020).

In our study, the increase in occupational participation was significant between the students, and only three of the twenty one occupations listed did not suffer any change. This finding can be justified by the fact they reported diminished levels of participation for study activities (i.e. studying $\&$ reading) which explains why they have a time-gap to be filled with other occupations during the pandemic, activities such as play, listening to music, meditation and self-care.

Time use indicates the level, quality and balance of occupational participation (Farnworth et al., 2004; O'Connell et al., 2010). Our findings identify different areas of occupational participation that were modified, where productive activities (study) were left in order to spend time on basic activities of daily living (self-care), leisure (listing to music, meditating), instrumental activities of daily living (domestic activities, cooking, take care of children and pets, being a carer) among others (American Occupational Therapy Association, 2020). However, these changes did not happen for the group of workers, where work was added as an extra activity in their home environment, in addition to the responsibilities of caring for children, domestic activities and being a familiar caregiver.

Overall, our findings concerning occupational participation of the groups studied can be discussed by the theoretical background of occupational adaptation (Kielhofner, 2008). Most of the participants reported elements which can be related to problems in their occupational adaptation, for example, when they expressed difficulties in performing what they needed to do or were expected to do. Their sense of familiar routine being changed by new habits and activities; which can be possibly be one of the reasons that influences their capacity and effectiveness for doing their work. 
Finally, our data about the mental health of the participants during the pandemic show alarming amounts of depression, anxiety and stress, which were more evident in the student sample. Despite using different measures than the other four studies, our data is similar in detecting mental health problems among students during COVID-19. In a study conducted in France, 291 students reported an increase of anxiety and moderate to severe stress during the confinement (Husky et al., 2020). Another study, conducted in China, assessed 7.143 college students who responded to a questionnaire which included the 7-item Generalized Anxiety Disorder Scale (GAD-7). This study found that economic and daily life conditions and delay in academic activities were correlated negatively with levels of anxiety; and these findings support the need of follow-up and care for students' mental health during the pandemics (Cao et al., 2020).

In Italy, 400 participants (students, and university administration workers) responded to a study where the results identified that bedtime hours, sleep latency and wake-up times increased during the pandemic, and mainly during lockdown. Delay in bedtime and wakeup were more pronounced among students. Moreover, $27.8 \%$ of the sample reported depressive symptoms, and 34.3\% anxious symptoms, particularly so for the students. Based on these findings, interventions for well-being are recommended during the pandemic (Marelli et al., 2020). Similar results were identified in a study conducted with 476 university students from Bangladesh, which found that, during the pandemic $15 \%$ of them had moderately severe depression, and $18.1 \%$ were severely suffering from anxiety. These authors recommend collaborative work between universities and Governments in order to tackle problems related to academic delays and mental health of students (Islam et al., 2020).

In Spain, using the same measurement we used for anxiety, depression and stress, similar results were identified for university students, and the conclusion reached was that these results related the difficulties of adaptation to the lack of academic activities within the university which was possibly causing stress among students. In face of these findings, the researchers recommend implementation of preventative programmes to reduce stress levels (Ozamiz-Etxebarria et al., 2020).

Finally our research presents association between occupational participation, time organisation and symptoms of mental health problems. Concerning the time organisation, one variable regulated by the habits and occupational roles, can be impacted by the "new" routine, and furthermore, in a broad sense, in the occupational adaptation (Lee \& Kielhofner, 2017). We observed that the students were the group with more difficulties in organizing their time when compared to the other two worker groups. This finding can be understood by the fact that entering in a new occupational role as a university student requires new responsibilities in order to fill this role, for example, in the tasks which they now need to perform. Such difficulties can be related to the process of internalizing an occupational role (Lin \& Fisher, 2020), and clearly illustrates difficulties in accomplishing new habits which then have to be adapted to the environmental restrictions. However, the other groups also reported difficulties in doing what they wanted or were expected to do; but in minor percentages, it is evident that the whole sample had difficulties in occupational participation as an impact of quarantine, a fact which is already recognised in the literature (Lin \& Fisher, 2020).

It is important to discuss the fact that occupational engagement has several dimensions which can have an influence on time organisation; since a person might need to organise time to identify, plan, practice and to sustain their work, among other 
factors (Forsyth \& Kielhofner, 2008). Under this perspective, the time disorganisation can compromise occupational engagement.

Further, association were found between symptoms of mental health problems for the students (anxiety, depression and stress) and lecturers (depression and stress) thus raising questions for further investigations in order to address the quality of occupational participation and the promotion of a positive occupational engagement. Current reviews have pointed the importance of occupational balance, which can be accomplished when a person performs a range of different occupations, but also has a balance between being active and rest/relaxation (Black et al., 2019). This discussion also leads us to think how occupational participation needs to be understood in terms of by the psychological, cognitive and emotional implications when a person performs occupations, and their feelings, responsibilities and choices taken into consideration (Black et al., 2019).

\section{Conclusion}

This study identified differences in occupational participation before and during the pandemic, among members of three public universities of Brazil. The increase in occupational participation is also followed by being overwhelmed and subsequent symptoms of depression, anxiety and stress. Time organisation and difficulties in effective performance of occupations appear to be related to levels of anxiety, depression and stress, mainly in the student sample.

Our study has several limitations. The first one is the small sample of participants who responded the research. The fact that the levels of depression, anxiety and stress in the sample were identified only during the pandemic and not before; a fact which does not allow us to affirm that these symptoms started with the beginning of the pandemic. There is no external validity, since it is a convenience sample and this research design does not permit us to generalize our findings for all Brazilian universities. Because we did not use a standardized, valid and reliable measure of occupational participation this might impact with biases in our results. Although we justified the lack of assessments for occupational participation in Brazil and understand that, despite our data, this cannot lead to generalized conclusions; it certainly contributes to the picture of occupational participation affecting people's lives before and during the pandemic.

Additionally, our findings highlight important issues for further study, following research questions such as: Can occupational engagement during pandemics have a positive effect? How health, well-being and quality of life can affect people in academic settings? How can occupational therapy help society in terms of changing lifestyle, routines and occupational roles in order to occupational adaptation needed during pandemics? How demographic data such as age, sex, income can influence on occupational participation of a group population? In addition, these first findings document changes in people's lives related to the pandemic policies of social isolation and working and studying remotely. Even supposing that the changes in occupational participation increased in all groups, a qualitative investigation needs to be conducted to understand how occupational engagement (subjective experience of doing things) as a result of occupational participation contributes positively to health, wellbeing and quality of life: core outcomes for the profession of Occupational Therapy. 


\section{Acknowledgements}

Prof. Dr. Ian Tracey, Liverpool, UK, for review this article. To CAPES: This work was carried out with the support of the Coordination for the Improvement of Higher Education Personnel - Brazil (CAPES) - Financing Code 001 - Scholarship holder Julia Andreza Gorla.

\section{References}

American Occupational Therapy Association - AOTA. (2020). Occupational Therapy Practice Framework: domain and Process. The American Journal of Occupational Therapy, 74(Suppl. 12), 1-87. http://dx.doi.org/10.5014/ajot.2020.74S2001.

Black, M. H., Milbourn, B., Desjardins, K., Sylvester, V., Parrant, K., \& Buchanan, A. (2019). Understanding the meaning and use of occupational engagement: findings from a scoping review. British Journal of Occupational Therapy, 82(5), 272-287. http://dx.doi.org/10.1177/0308022618821580.

Brasil. Ministério da Saúde. (2020). Diretrizes para diagnóstico e tratamento da covid-19. Brasília: Ministério da Saúde.

Brooks, S. K., Dunn, R., Amlôt, R., Rubin, G. J., \& Greenberg, N. (2018). A systematic, thematic review of social and occupational factors associated with psychological outcomes in healthcare employees during an infectious disease outbreak. Journal of Occupational and Environmental Medicine, 60(3), 248-257. http://dx.doi.org/10.1097/JOM.0000000000001235.

Cao, W., Fang, Z., Hou, G., Han, M., Xu, X., Dong, J., \& Zheng, J. (2020). The psychological impact of the COVID-19 epidemic on college students in China. Psychiatry Research, 287, 1-6. http://dx.doi.org/10.1016/j.psychres.2020.112934.

Centers for Disease Control and Prevention - CDC. (2020). Deciding to go out. Retrieved from: https:/www.cdc.gov/coronavirus/2019-ncov/daily-life-coping/deciding-to-go-out.html

Farnworth, L., Nikitin, L., \& Fossey, E. (2004). Being in a secure forensic psychiatric unit: everyday is the same, killing time or make the most of it. British Journal of Occupational Therapy, 67(10), 430-438.

Fisher, G., Parkinson, S., \& Haglund, L. (2017). The environment and human occupation. In: R. R. Taylor (Ed.), Kielhofner's model of human occupation (pp. 91-106). Philadelphia: Wolters Kluwer.

Forsyth, K., \& Kielhofner, G. (2008). Occupational engagement: how clients achieve change. In G. Kielhofner (Ed.), Model of Human Occupation (pp. 171-184). Philadelphia: Wolters Kluwer.

Husky, M. M., Kovess-Masfety, V., \& Swendsen, J. D. (2020). Stress and anxiety among university students in France during Covid-19 mandatory confinement. Comprehensive Psychiatry, 102, 152191. http://dx.doi.org/10.1016/j.comppsych.2020.152191.

Islam, M. A., Barna, S. D., Raihan, H., Khan, M. N. A., \& Hossain, M. T. (2020). Depression and anxiety among university students during the COVID-19 pandemic in Bangladesh: a web-based cross-sectional survey. PLoS One, 15(8), 1-12. http://dx.doi.org/10.1371/journal.pone.0238162.

Kielhofner, G. (2008). Dimensions of doing. In G. Kielhofner (Ed.), Model of Human Occupation (pp. 101-109). Philadelphia: Wolters Kluwer.

Kielhofner, G., \& Neville, A. (1983). The Modified Interest Checklist. Unpublished manuscript. Model of Human Occupation Clearinghouse. Chicago: University of Illinois.

Ledford, H., Cyranoski, D., \& Van Noorden, R. (2020). The UK has approved a COVID vaccine - here's what scientists now want to know. Nature, 588, 205-206. http://dx.doi.org/10.1038/d41586-020-03441-8.

Lee, S. W., \& Kielhofner, G. (2017). Habituation: Patterns of daily occupation In R. R. Taylor (Ed.), Kielhofner's Model of Human Occupation (pp. 291-310). Philadelphia: Wolters Kluwer.

Liang, L., Ren, H., Cao, R., Hu, Y., Qin, Z., Li, C., \& Mei, S. (2020). The Effect of COVID-19 on Youth Mental Health. The Psychiatric Quarterly, 91, 841-852. http://dx.doi.org/10.1007/s11126-020-09744-3. 
Lin, T. T., \& Fisher, G. (2020). Applying the model of human occupation during the pandemic stay-at-home order. The Open Journal of Occupational Therapy, 8(4), 1-7. http://dx.doi.org/10.15453/2168-6408.1770.

Marelli, S., Castelnuovo, A., Somma, A., Castronovo, V., Mombelli, S., Bottoni, D., Leitner, C., Fossati, A., \& Ferini-Strambi, L. (2020). Impact of COVID-19 lockdown on sleep quality in university students and administration staff. Journal of Neurology, 268, 8-15. http://dx.doi.org/10.1007/s00415-020-10056-6.

Matrajt, L., \& Leung, T. (2020). Evaluating the effectiveness of social distancing interventions to delay or flatten the epidemic curve of coronavirus disease. Emerging Infectious Diseases, 26(8), 1740-1748. http://dx.doi.org/10.3201/eid2608.201093.

Mheidly, N., Fares, M. Y., \& Fares, J. (2020). Coping with stress and Burnout Associated With Telecommunication and Online Learning. Frontiers in Public Health, 8, 1-7. http://dx.doi.org/10.3389/fpubh.2020.574969.

Moraes, R. F. (2020). Determinants of physical distancing during the covid-19 epidemic in Brazil: effects mandatory rules, numbers of cases and duration of rules. Ciência \& Saúde Coletiva, 25(9), 33933400. http://dx.doi.org/10.1590/1413-81232020259.21892020.

O’Connell, M., Farnworth, L., \& Hanson, E. C. (2010). Time use in forensic psychiatry: a naturalistic inquiry into two forensic patients in Australia. International Journal of Forensic Mental Health, 9 , 101-109. http://dx.doi.org/10.1080/14999013.2010.499558.

Oakley, F., Kielhofner, G., Barris, R., \& Reichler, R. K. (1986). The role checklist: development and empirical assessment of reliability. OTJR, 6(3), 157-170. http://dx.doi.org/10.1177/153944928600600303.

Organização Pan-Americana da Saúde - OPAS. (2020). Folha informativa - COVID-19 (doença causada pelo novo coronavirus). Retrieved from: https://www.paho.org/pt/covid19

Ozamiz-Etxebarria, N., Dosil-Santamaria, M., Picaza-Gorrochategui, M., \& Idoiaga-Mondragon, N. (2020). Stress, anxiety, and depression levels in the initial stage of the COVID-19 outbreak in a population sample in the northern Spain. Cadernos de Saúde Pública, 36(4), 1-9. http://dx.doi.org/10.1590/0102-311x00054020.

Pablo, C. G. H., Fan, C. W., \& Kielhofner, G. (2017). Dimensions Of Doing. In R. R. Taylor (Ed.), Kielhofner's Model Of Human Occupation (pp. 107-122). Philadelphia: Wolters Kluwer.

Rafael, R. M. R., Neto, M., Carvalho, M. M. B., David, H. M. S. L., Acioli, S., \& Faria, M. G. A. (2020). Epidemiologia, políticas públicas e pandemia de Covid-19: o que esperar no Brasil? Revista de Enfermagem da UERJ, 28, 1-6. http://dx.doi.org/10.12957/reuerj.2020.49570.

Silva, G. A., Jardim, B. C., \& Santos, C. V. B. (2020a). Excesso de mortalidade no Brasil em tempos de COVID-19. Ciência \& Saúde Coletiva, 25(9), 3345-3354. http://dx.doi.org/10.1590/141381232020259.23642020 .

Silva, T. R., Mariotti, M. C., \& Bridi, A. (2020b). Aprendendo a lidar com as mudanças de rotina devido ao COVID-19: orientaçóes práticas para rotinas saudáveis. Revista Interinstitucional Brasileira de Terapia Ocupacional, 4(Supl. 3), 519-528. http://dx.doi.org/10.47222/2526-3544.rbto34250.

Souza, K. R., Santos, G. B., Rodrigues, M. A. S., Felix, E. G., Gomes, L., Rocha, G. L., \& Peixoto, R. B. (2021). Trabalho remoto, saúde docente e greve virtual em cenário de pandemia. Trabalho, Educação e Saude, 19, 1-14. http://dx.doi.org/10.1590/1981-7746-sol00309.

Teixeira, M. R., \& Dahl, C. M. (2020). Recriando cotidianos possíveis: construção de estratégias de apoio entre docentes e estudantes de graduação em terapia ocupacional em tempos de pandemia. Revista Interinstitucional Brasileira de Terapia Ocupacional, 4(Suppl. 3), 509-518. http://dx.doi.org/10.47222/2526-3544.rbto34425.

Vignola, R. C., \& Tucci, A. M. (2014). Adaptation and validation of the depression, anxiety and stress scale (DASS) to Brazilian Portuguese. Journal of Affective Disorders, 155, 104-109.

Vindegaard, N., \& Benros, M. E. (2020). COVID-19 pandemic and mental health consequences: systematic review of the current evidence. Brain, Behavior, and Immunity, 89, 531-542. http://dx.doi.org/10.1016/j.bbi.2020.05.048. 
World Federation of Occupational Therapy - WFOT. (2020). Public Statement - Occupational Therapy Response to the COVID-19 Pandemic. Retrieved from: https://www.wfot.org/about/public-statementoccupational-therapy-response-to-the-covid-19-pandemic.

World Health Organization - WHO. (2020). Coronavirus disease (COVID-19) advice for the public.

Retrieved from: https://www.who.int/emergencies/diseases/novel-coronavirus-2019/advice-for-public.

\section{Author's Contributions}

Glenda Miranda da Paixão: Project design, data analysis, and writting. Adriene Damasceno Seabra: Project design, data analysis, and writting. Adrine Carvalho dos Santos Vieira: Project design, data analysis, and writting. Julia Andreza Gorla: writing and formatting and final review. Daniel Cezar da Cruz: wirting, literature review and final review. All authors approved the final version of the text.

\section{Funding Source}

Coordination for the Improvement of Higher Education Personnel - Brazil (CAPES)

\section{Corresponding author}

Julia Andreza Gorla

e-mail: gorla.ju@gmail.com

\section{Section editor}

Profa. Dra. Ana Luiza Alegretti 


\section{TERAPIA}

Original Article

\section{Appendix 1. Checklist of Occupational Participation before and during the pandemics}

- Instructions:

Read the checklist below and inform in what occupations you had the participation before the pandemics and during the pandemics. For each column next to a specific occupation you have to mark only one option.

First, tick if you perform the occupation before the pandemics where:

$0=$ I do not participate

$1=$ I participate

$2=$ I participate moderately

$3=$ I participate vigorously

Level of participation

Occupations

0

1

2

3

\begin{tabular}{c}
\hline Hand crafts \\
\hline Before Pandemics \\
\hline During the Pandemics \\
\hline Watch TV \\
\hline Before Pandemics \\
\hline During the Pandemics \\
\hline Take care of children \\
\hline Before Pandemics \\
\hline During the Pandemics \\
\hline Self-care \\
\hline Before Pandemics \\
\hline During the Pandemics \\
\hline Gardening \\
\hline Before Pandemics \\
\hline During the Pandemics \\
\hline Domestic activities \\
\hline Before Pandemics \\
\hline During the Pandemics \\
\hline Take care of pets \\
\hline Before Pandemics \\
\hline During the Pandemics \\
\hline Cooking \\
\hline Before Pandemics \\
\hline During the Pandemics \\
\hline
\end{tabular}

Received on Feb. 1, 2021; $1^{\text {st }}$ Revision on June 1, 2021; 2nd Revision on Aug. 12, 2021; Accepted on Sept. 10, 2021. (c) (i) This is an Open Access article distributed under the terms of the Creative Commons Attribution License, which permits unrestricted use, distribution, and reproduction in any medium, provided the original work is properly cited. 
Occupations

0

1

2

3

Studying

Before Pandemics

During the Pandemics

Writing

Before Pandemics

During the Pandemics

Physical activity

Before Pandemics

During the Pandemics

Play

Before Pandemics

During the Pandemics

Reading

Before Pandemics

During the Pandemics

Meditation

Before Pandemics

During the Pandemics

Listening music

Before Pandemics

During the Pandemics

Using social media

Before Pandemics

During the Pandemics

Work from the office

Before Pandemics

During the Pandemics

Work remotely

Before Pandemics

During the Pandemics

Volunteering

Before Pandemics

During the Pandemics

Learn new skills

Before Pandemics

During the Pandemics

Caregiving

Before Pandemics

During the Pandemics 
- The following five questions are about your routine during the pandemics, please answer only one option "Yes" or "no":

\begin{tabular}{cc}
\hline Question & \multicolumn{2}{c}{ Answer } \\
\cline { 2 - 2 } Did I organize my time to perform satisfactorily? & \\
\hline
\end{tabular}

Did I have difficulties performing all occupations I wanted to or expected to do?

Did I begin new habits and occupations?

Did I sustain these new habits and occupations?

Did I follow the rules of social isolation (left home only for essential needs)? 